\title{
rehabilitation for change in fiji: a women's initiative
}

\begin{abstract}
Peni Moore ${ }^{1}$
describes the Fiji prison system and how a local women's NGO - Women's Action for Change - helped sensitise inmates to the consequences of their actions. This was achieved through theatrical performances, exercises and games, and helped set participants on the path to rehabilitation.
\end{abstract}

WHEN I BEGAN this chapter, Fiji was a democratic country with an elected People's Coalition Government led by the Fiji Labour Party. The last few weeks have given Fiji something quite different. ${ }^{2}$

The People's Coalition Government was the first of any Fijian government to show any interest in prison rehabilitation. It established a Cabinet Subcommittee to review existing conditions and programs.

Women's Action for Change (WAC) has been conducting programs in the prison for the last eighteen months, using drama as a means of rehabilitation and education. Writing to the Permanent Secretary for Justice, the Assistant Commissioner of Prisons praised our rehabilitation program. He concluded that: 'The Prisons Department strongly supports the continuation of the WAC program. The group should therefore be give the opportunity to further develop their Rehabilitation Plans and thus assist in the overall realisation of the Department's mission in the rehabilitation of inmates.'

However, on 19 May seven armed men invaded the parliamentary complex in Suva taking Members of Parliament as hostages. At the time of writing, this has resulted in army control of the country. Our prospects of receiving assistance from 
government now look bleak. Because of the violent act perpetrated by George Speight and his supporters, poverty is likely to become more extreme in our country and crime will escalate as the frustrations and problems increase. WAC is aware that our program will now be needed more than ever and that we will need to work in more prisons. We have no idea, however, where the necessary financial assistance will come from.

\section{Background}

Fiji has a total population of 775,100 people. Fifty-one per cent (approximately 394,000) are men. Of these, 50 per cent are ethnic Fijians, 44 per cent are Indo-Fijian, and 6 per cent are mixed race or 'others' as they are classified in Fiji. One hundred and sixty-six thousand men are between the ages of 20-50 (slightly more than two-fifths of the male population). Of these 166,000 , about 1,000 will be in prison in any one year.

There are eight prisons in Fiji. Some are classed as holding prisons for prisoners with sentences less than three years and those who are on remand (e.g. not yet convicted). The prison in Suva, named Korovou, takes in men with various lengths of sentences and men who are on remand, yet is considered a holding prison. Naboro prison is a prison farm made up of four types of security blocks - minimum, medium and maximum security, and pre-release. The Nasinu prison is for young and/or first-time offenders. There is only one women's prison that takes women in from all over Fiji. It has the capacity for 30 women but usually has about 12-15 inmates. There are usually less than 9 convicted women in prison at any one time with the remainder being made up of remandees.

Statistics collected by the prison authorities break the prison population down into age groups and ethnicity. Over the five year period from 1994 to 1998 (the most recent statistics available to us), the number of male prisoners has fluctuated. However, as Table 1 shows, the number of men in prison hovers around 1,000 per year. Many of the prisoners are repeat prisoners: 48 per cent in 1994; 41 per cent in 1995; 41 per cent in 1996; 40 per cent in 1997; and 33 per cent in 1998. 
Table 1 Male prisoners by previous convictions, 1994-98

\begin{tabular}{lrrrrr} 
Previous convictions & 1994 & 1995 & 1996 & 1997 & 1998 \\
\hline None & 622 & 693 & 530 & 572 & 745 \\
One & 341 & 276 & 161 & 154 & 169 \\
Two & 150 & 143 & 97 & 125 & 66 \\
Three & 84 & 71 & 117 & 105 & 124 \\
\hline Total & 1197 & 1183 & 905 & 956 & 1104
\end{tabular}

Source: Fiji Ministry of Justice - Prisons Department

NB. Female prisoners have not been included in these statistics because of the very low numbers.

Prisoners ages fall mostly in the range of 17 to 50 years as Table 2 shows.

Table 2 Male prisoners by age, 1994-98

\begin{tabular}{lrrrrr} 
Age group & 1994 & 1995 & 1996 & 1997 & 1998 \\
\hline Under 17 years & 3 & 2 & 6 & 1 & 0 \\
17-20 years & 345 & 296 & 173 & 233 & 238 \\
$21-25$ years & 415 & 409 & 360 & 363 & 433 \\
26-50 years & 420 & 471 & 349 & 340 & 409 \\
Over 50 years & 14 & 5 & 17 & 19 & 24 \\
\hline Total & 1197 & 1183 & 905 & 956 & 1104 \\
\hline
\end{tabular}

Source: Fiji Ministry of Justice — Prisons Department

Admission to prison can also be looked at by ethnicity. The largest ethnic group are indigenous Fijians who are seriously over-represented. As pointed out earlier, the breakdown of men by ethnicity in the general population is 50 per cent indigenous Fijian, 44 per cent Indo-Fijian, and 6 per cent other. 
Table 3 Male prisoners by ethnicity, 1994-98

\begin{tabular}{lrrrrr} 
Ethnicity & 1994 & 1995 & 1996 & 1997 & 1998 \\
\hline Indigenous Fijian & 823 & 811 & 689 & 865 & 913 \\
Rotuman & 2 & 9 & 5 & 5 & 2 \\
Indo-Fijian & 293 & 290 & 290 & 126 & 180 \\
Other & 57 & 67 & 22 & 26 & 9 \\
\hline Total & 1175 & 1177 & 1006 & 1022 & 1104
\end{tabular}

Source: Fiji Ministry of Justice — Prisons Department

It will be noted that the total numbers for each year differ in Table 3, compared with Tables 1 and 2. This is because Table 3 reflects the number of admissions, whereas the other two tables give the numbers resident in the prison at the time of data collection by the Ministry.

The statistics for ethnicity sound an alarming note for the number of indigenous Fijians compared to other races. However, this is not to say that men of other races do not commit crime. Previous research ${ }^{3}$ provides some clue as to why this happens. It appears to relate to the kinds of crimes committed by the different groups. Certain crimes, such as robbery with violence, drugs, rape, and murder, have high conviction rates and almost invariably attract a prison sentence. Convictions and prison sentences are rarer, however, in the cases of fraud and white-collar crime.

Since WAC started performing community theatre six years ago we have visited seven prisons around Fiji with plays on social issues. In 1997 the Commissioner of Prisons requested that WAC produce a play to generate community support for prisoners when they re-entered the community. Lack of support from family and the community at large was seen as a contributing factor to the high recidivism rates.

As a women's organisation, WAC was particularly interested in working with perpetrators of violence. Our aim was to help bring about a change in attitude and, hopefully, to reduce the number of violent situations and types of violence faced so regularly by women in Fiji. For WAC, working in the 
prisons gave us the opportunity to confront the issues and show the men how we as women felt. The advantage we had in using theatre games and 'Playback' performances, as well as community theatre, was that the men got to trust all six of us (the WAC members). They participated and told their stories, discussed their feelings and were able to see how some of their actions, behaviour and attitudes affected women. As you will hear from the evaluation it seemed to make a difference.

In 1998, with funding from the Canada Fund, WAC produced a play called 'Homecoming'. This was written specifically to encourage community support and an understanding of what it is like for men being released from prison and returning to their communities. WAC researched the information used in the play by talking with ex-prisoners and getting their assistance to contact others. The ex-prisoners gave their approval of the final production before it was taken out into the community. Thereafter, the play was performed in over forty locations within the major islands of Fiji over a twelve-month period.

During the twelve months in which the play was being performed in the communities, the Commissioner for Prisons invited WAC to submit a proposal for drama to be used with the prison population. Permission was granted by the Commissioner to run theatrical performances that were aimed at improving the communication skills of prisoners and to enhance their self-esteem. These two goals were seen as very important at the start of the trial rehabilitation programs with the inmates. It was hoped that working in this way would help prevent them from re-offending. The two prisons chosen for WAC rehabilitation trials were the young and first offenders facilities at Nasinu and the Naboro Pre-release complex. Nasinu was chosen because the authorities hoped that the younger men would be the most receptive. The Naboro Pre-release was chosen because of the imminent release of the inmates and the need to provide them with skills that they could use in the immediate future.

It is important to note that no other programs dealing specifically with rehabilitation were being run. At the time of 
their inception, the rehabilitation trials included only minimal educational and training programs. Sessions were conducted mainly in the Nasinu Prison. Because of the impact of the WAC programs, the authorities requested that they be continued at Nasinu and the Naboro Pre-release. This work continues to this day and, hopefully, despite the political crisis will continue into the future.

With further financial assistance from the New Zealand Office of Development Assistance (NZODA), WAC was able to extend the rehabilitation programs into the Korovou Women's Prison and the Lautoka Prison. WAC now spends three days a week working in the various prisons and we have also been requested to consider expanding into the medium and minimum security facilities at Naboro. Should this eventuate it will take place within the next twelve months.

\section{Aims}

The main aim of this project was to try and change the attitudes and behavior of the inmates and to encourage non-violent ways of dealing with problems. In order to do this, WAC worked on building up the self-esteem and confidence of the prisoners. As a women's organisation, we were also particularly concerned with changing male attitudes towards women in order to reduce the violent crimes and negative behavior directed at them. Domestic violence is common in Fiji amongst all races and people from all socio-economic backgrounds. The prison authorities were interested in seeing an improvement in the inmates attitudes and behaviour, and, ultimately, in discouraging them from re-offending.

\section{Methodology}

WAC decided to use 'Playback' theatre, exercises and games, because earlier evaluations had showed that these methods were successful in a number of ways. The games, exercises and Playback techniques:

- $\quad$ had been used by the actors to unwind;

- $\quad$ got people participating much more quickly at workshops; 
- $\quad$ have a 'magic' of their own;

- $\quad$ bring people together;

- $\quad$ are non-threatening and thus allow people to 'feel safe';

- $\quad$ are a logical method for getting discussion and participation.

I will now outline the way in which we introduced the training and rehabilitation programs at the four prisons in which we are currently working. The first program was held at Nasinu Prison in 1998. As mentioned earlier, this prison is for first-time and young offenders. The prison has approximately 100 men ranging in age from seventeen to twenty-five years. Although they are classed as first offenders, most of the men had in fact committed a range of crimes that eventually resulted in a prison sentence. The prison authorities gave us thirty of the inmates with the highest level of education and we worked with them for three weeks, three days a week, three hours a day. Altogether we worked for twenty-seven hours in the initial part of the rehabilitation program. We spent the first hour each day doing theatre games that were designed to encourage mental and physical agility without being competitive. The second hour was spent in smaller groups, playing games and exercises to improve their acting and music skills and to enable them to participate in the Playback theatre performances. The third hour was spent performing Playback on issues that had been raised by the inmates. In the prisons, WAC works on a co-operative basis with the men. The games and exercises are especially designed in order to encourage participation on a non-competitive basis.

A brief evaluation of the program at Nasinu showed that the work was successful. This led to WAC being invited to take the program to the Naboro Pre-release section, starting in early 1999. Pre-release is that section of Naboro Prison kept for the best-behaved prisoners and those about to be released back into the community after serving their sentences. There are up to thirty inmates in this section at any one time. All inmates participated in the three week training, which consisted of two hours a day for three days a week. Just as in the preliminary training schedule, the games and exercises were designed to 
increase mental and physical agility on a non-competitive basis. The inmates were given the choice to join in the acting and the music part of the Playback performance. Many of them participated. After this initial period we began regular visits to Nasinu and Naboro Pre-release.

After the initial training at Nasinu, WAC started the rehabilitative program on a weekly basis working for a threehour session. The prison population at Nasinu is organised into five groups and it was intended that WAC would work with all of them. However this has not always been the case because of the way in which the prison population is organised for work detail and because of the logistics involved in the organisation of each group.

Over the life span of the program at Nasinu and at pre-release, changes have been made to the structure of the three- and two-hour rehabilitative sessions. Initially the first hour was spent on games and exercises as described in the initial training, followed by one hour of exercises to improve musical and acting ability and then one hour of Playback. With the two-hour program, the acting skills were incorporated into the games section, leaving three quarters of an hour for a Playback performance.

After we had completed a number of sessions we, WAC, noticed a tremendous interest in music by all the prisoners participating in the program. This prompted us to respond to this interest. We changed the program to devote half the time to games and exercises, and the second half to songwriting around specific themes using popular tunes as the basis. Most of the songwriting was done in Fijian, the language preferred by most of the inmates because they are not confident to write in English. The themes of the songs covered a wide range of issues as verbalised by the prisoners in their personal storytelling: e.g. their likes and dislikes of life in prison, how they felt about women, and other issues such as alcohol.

With the NZODA funding, WAC was able to begin working in the only women's prison in Fiji. We had to make a few adjustments to our established process because of the 
shorter session times (two hours instead of three) and having a smaller number of prisoners at each session. We noticed several distinct differences between the female and male prisoners. The women were quick on word games and in writing songs. They were articulate when telling their stories and were much more willing to join in acting out the stories. However, they did not enjoy the physically demanding exercises that really excited the men and which they played with much vigour and noise. The women also had less developed musical skills and were not as confident as the men when it came to singing and playing musical instruments.

WAC has recently begun to work at Natabua Prison in Lautoka. It is the largest holding prison on the western side of the main island of Viti Levu. Its population of approximately 120 inmates is divided into four dormitories and three cell blocks. Convicted and remand prisoners are housed at Natabua. Men are held here if they have sentences of less than three years and either come from the western side of the island or committed their crime there. Due to staff shortages at Natabua, WAC was not able to conduct the full training program. We had to restrict our activities to two 2-hour sessions every second week, which meant two dormitories a day. All four dormitories are covered in a month. WAC is using these sessions as an introduction to the methods. The more sensitive issues will be discussed during Playback once the inmates are used to and comfortable with us. The first hour and fifteen minutes of the session is spent in playing games, with the next three quarters of an hour on Playback. The program is totally different from anything these men have ever experienced and we have had an enthusiastic response with full participation from the men we were assigned to work with. It is hoped that as we work with them more we can begin on the important issues of violence and women. As yet we are still getting to know and trust each other.

With the prisoners really enjoying the program and having learnt and developed new skills, WAC is thinking about the next stage in the process. We are considering introducing drawing and other art forms using murals to complement the 
storytelling. The artwork would relate to a theme relevant to individual prisoners who feel more comfortable expressing themselves through pictures rather than words.

We intend to compile the songs written during our program at the various prisons into an informal (and free) collection of 'Songs from the Dark Side'. This will include the Fijian and English translations of songs written in Nasinu, Korovou women's prison, Naboro Pre-release and possibly Lautoka.

Examples of songs written about life in prison from the Nasinu men are shown below. The first song set to a popular old Fijian tune chuluchululu is about what men like in prison. We have translated the words into English.

\section{What I Like In Prison}

Chuluchululu today is Wednesday (2 times)

Today it's sports, and the ground is shaking (2 times)

Screams and laughter very loud

Chuluchululu, today is Friday (2 times)

Inside the classroom of RTC (2 times)

The WAC is here with us today

Saturday morning slowly appears (2 times)

Bath, quickly, shave and neatly dress (2 times)

Darling we're going to meet today

Inside the dormitory, I must let you know (2 times)

Everybody's quiet and missing home

Laughing slowly rings out

Eddie Lovet sets one song about things men hate about prison to a tune. The English translation is shown.

\section{What We Do Not Like In Prison}

Think back at the past time

When I was still outside

Freedom life I used to have

And I waste it by mistake 
Chorus Oh my precious life

Sadness is inside me

Hard work with no pay

Burden feeling everyday

Now I am a loser

Freedom I used to have has disappeared

Leadership to describe

Very tough and so tight

Tone words without soft spoken

Neither my heart will be broken.

\section{A rap version of what we don't like about prison}

When I walk through the dorm

Of the shadow of sin

I take a look at my life

And bring inside me

Working conditions

Hot or rainy weather

Limited time for all of us together.

Tell me why are we

So blind to see

No privacy

For you and me

Power and money,

Money and power

Food and the taste,

Hour after hour

Officers behaviour,

Good and bad

But sometimes they're being so slack

Tell me why are we

So blind to see

No privacy

For you and me 


\section{Leaving Prison}

(This song was written in English)

Goodbye, goodbye Carlos

You'll be going home tomorrow

This is your last day with us

But tomorrow you'll be having your freedom

Chorus You'll be gone, you'll be gone

And don't come back

And we hope that we'll meet outside

But remember don't play the bad way

You'll be gone, you'll be gone

And don't come back

\section{Results}

In their report to the Permanent Secretary for Justice, the assessors of our work at Nasinu Prison stated that the 'Inmates had shown marked improvements in their attitudes, self-expression, concentration in classrooms'... Formal evaluations were also carried out at Nasinu through the officer in charge of education, Setareki Tuinona. Some comments he received from the prisoners included:

- I I never thought I could stand up in front of a crowd and speak. Now I know I can.'

- $\quad$ I feel I could go for a job now.'

- 'We feel more like a family here.'

At Naboro, WAC conducted a written evaluation in Fijian and English. Men who did not have written language skills were assisted in completing their forms. Here are some of the things they said they liked:

- $\quad$ First thing: I liked the atmosphere. Second thing: I liked the truth that was brought up about our relationships, things that we did wrong and also about our feeling towards someone, say a beloved one.

- I like the drama plus the songs and the knowledge about family living. I really liked the drama about prisoners going back into society. 
- Most of it actually about the drama regarding the importance of relationships through loving and caring.

- It helps me to make decisions and also build up my life to be much more stable.

- My mind broadens, and I feel more confident.

The men said that they had made changes in themselves:

- I realise that I need to be more independent. To have high self-esteem and a positive outlook at things.

- I have noticed that for the past three weeks I have changed from being to being - well, you know - to a respectful guy - from being hate to being love.

- I have changed my attitude to be more friendly towards fellow inmates. And also my mind is more active and refreshed.

- My mind starts to think in a positive way rather than lose hope.

- $\quad$ Now I'm more honest in what I say and do.

- $\quad$ This program has improved my life and built up my confidence.

Other changes that they have noticed are more to do with their learning:

- $\quad$ Learnt more about the facts of life. See females as equal. First to love and care for women rather than looking at them as nothing. Second to protect myself from being around with the wrong gang. Do not abuse anybody.

- My relationships with my beloved ones have to go through caring and loving. [I must] stop being rude and crazy but live in trust and honesty.

- I have learnt the basics in acting and music; also how to better manage my family.

- $\quad$ So many things actually [to aspire to] but to say just a few: be a good citizen, have one partner in life, do not become addicted to drugs or alcohol.

The evaluation at the Women's Prison was done informally between the officer in charge (Anna) and the inmates. She reported to WAC that there had been a marked change in 
attitudes. All of the inmates were able to communicate much better and they were more alert and happy.

Because we are still at an early stage in the process at the Natabua prison in Lautoka, no formal evaluation has yet been done. Judging by the enthusiastic participation of the inmates the program is appreciated and is already making an impact on their lives.

\section{Conclusion}

We have been working in the prisons for nearly two years now. During this time we have developed a close working relationship with the prison authorities and with many of the prisoners with whom we come into contact. Some of the men are now being released. Some keep in touch with us and we have an informal network that we use to contact men when we know of some paid work they can do. This provides some support. Employment for the ex-prisoners is a major issue. Some of the men revert to illegal methods of employment as they see this as their only option to earn money. The coup has had a negative impact on the economy. Workers are losing their jobs and unemployment is increasing rapidly. Income generating projects have had to be shelved because many relied on the tourist industry. This industry is almost non-existent at the moment. In the prisons men learn how to garden, from the clearing of the grounds through to the harvesting. However, many of them will not be able to put these skills into practice when they are released because they live in the Suva area where low cost housing and available land are scarce. Growing crops in Suva is a risky business at the best of times, because of stealing. With more and more people living without a regular or sufficient income, the stealing of crops is likely to increase.

We have seen changes occur in the men and women prisoners and they are documented in the evaluation as well as in the report from the Assistant Commissioner. We believe that the work we do with prisoners is important. We are convinced that it makes a difference to their lives in prison and we are hopeful that they will carry some of the learning with them 
when they return to their communities. The most convincing aspect of the rehabilitation program has been the evidence of transformation in the prisoners, in the obvious changes in their attitudes and behaviour and, especially, in the improvement of their self-esteem. In order to continue with this work it is important that WAC be given the resources and support to expand the program to other prisons. This has already been discussed. At present our future is bleak and who knows what we can expect!

One of the major issues for WAC is the reality that re-entry into life outside prison is a major and difficult challenge. Inside prison the inmates are a 'captive' population with little else to interest them. WAC is able to use this disadvantage to effect changes. By making the men realise that they do have feelings, and by enabling them to recognise that they too are capable of goodness, foundations are laid for them to improve their future behaviour. However, when they are released the men receive little or no reinforcement from society to continue to strengthen the changes they have started to make. They come out to poor prospects of work and no money. Their families expect them to behave better now, but again they experience peer pressure to act as they did before. They face the enticements of alcohol. The odds can be overwhelming. Those that are able, come to WAC, a place and a group of people that they now regard as 'safe'. At the moment we do not have the facilities to assist them to any great extent. It is our dream to create an income generating project by using the prisoners. Art and carpentry projects would form the basis of income generation, as these are skills that many men have and which are in demand by the community. Another aspect of the dream is to continue the work on increasing their self-esteem, using exercises and programs similar to those being implemented in the rehabilitation project.

Through our work in the prisons we have learnt many times over the years that until the inner person feels good the outer person will not be able to change or survive.

Options for ex-prisoners are bleak indeed, but WAC will 
continue to work with the prison population both now and in the future, providing we have the necessary funding. We have the commitment and the motivation to work and the intention to further develop communication skills, improve self-esteem, and develop understanding between women and men and work towards a less violent society.

\section{Endnotes}

1 I'd like to thank Peggy Duncan for her assistance in editing this paper.

2 The conference was held several weeks after George Speight's armed takeover of the Parliamentary complex in Suva.

3 Adinkrah, Mensah 1995. Crime, Deviance and Delinquency in Fiji 